\title{
Assessment of profenofos exposure an endocrine disrupting chemical in relation with serum testosterone alterations
}

\author{
Shakeel Ahmed Memon*, Nasreen Memon, Shamsuddin Ahmed \\ Shaikh, Zubeda Butt and Bhojoo Mal \\ Department of Zoology, University of Sindh, Jamshoro-76080, Pakistan \\ *Corresponding author email: shakeel_memon70@yahoo.com Phone number: 0092300-3069383 \\ Citation \\ Shakeel Ahmed Memon, Nasreen Memon, Shamsuddin Ahmed Shaikh, Zubeda Butt and Bhojoo Mal. Assessment \\ of profenofos exposure an endocrine disrupting chemical in relation with serum testosterone alterations. Pure and \\ Applied Biology. Vol. 4, Issue 1, 2015, pp 1-8
}

\begin{tabular}{lcc}
\hline \hline Received: 16/11/2014 & Revised: 19/12/2014 & Accepted: 20/12/2014 \\
\hline \hline
\end{tabular}

\section{Abstract}

The present study was conducted to investigate the toxic effects of endocrine disrupting chemical (EDC) on male reproductive function. Eighty male spray workers were participated and exposed to Organophosphate (Profenofos 500EC) insecticide to evaluate the alterations in serum testosterone level. During study period participants were assessed regarding their exposure to pesticides, protective tools and health conditions. Bloods samples were collected before and after spraying pesticide for the assessment of serum testosterone. Results were analyzed statistically. It was revealed that $70 \%$ of the post exposure spray workers had significant decrease in the serum testosterone $(4.40 \pm 1.25 \mathrm{ng} / \mathrm{ml} \mathrm{P}<0.01)$ as compared to pre exposure to spray that was $5.80 \pm 0.78 \mathrm{ng} / \mathrm{ml}$. Out of these $70 \%,(21 \%)$ spray workers were recorded with below normal level of serum testosterone $(2.73 \pm 0.30 \mathrm{ng} / \mathrm{ml})$. Clinical symptoms related to pesticide exposure dizziness, headache, joints pain, nausea, skin and eyes allergy were observed. It was concluded that profenofos may inhibit serum testosterone synthesis by disrupting hypothalamic, pituitarytesticular axis could impair the reproductive function in spray workers.

Key words: Endocrine disruptor;Profenofos; Spray worker;Testosterone

\section{Introduction}

The use of pesticide in agriculture sector has increased throughout the world especially in the developing countries like Pakistan. Pesticides and related agrochemicals are used for controlling noxious pests to increase the yield of crops. On the other hand, indiscriminate use of pesticides is causing severe environmental problems. Controlled use of pesticides is an essential aspect to avoid agrochemical toxicity.
Besides environmental issues, pesticides also cause severe health related problems in living beings by influencing the blood and organs. The adverse effects of pesticides may disrupt the endogenous hormones and endocrine system. Consequently the antiandrogenic effects of various pesticides disrupt the testosterone production in human [1]. Exposure to pesticides produces numerous biochemical and physiological alterations in human and their population in 
the agriculture fields [2, 3]. Many pesticides are capable to disrupt the synthesis of sex hormones, which can cause reproductive disorders such agrochemicals have been documented as endocrine disrupting chemicals EDCs [4]. The farmers/spray workers are directly exposed to pesticides through occupational activities and spraying pesticides on crops. Thus due to mishandling and inefficient safety measures exhibit significant health problems in spray workers by accumulation of pesticide residues in their body. Therefore pesticide exposure impairs normal reproductive process in humans [5] by disrupting androgenic activities and cause disturbances in the mechanism of steroidogenesis at testicular tissues [6].Testosterone hormone performs a crucial role in maintaining fertility and reproductive development in male. The disruption in the production of testosterone by (EDCs) inhibits the important process of male gonadal development [7]. However, very few studies in vivo \& in vitro have been done on sex hormones disruption and reproductive abnormalities [8, 9]. Profenofos is a moderate contaminating chemical and absorbed through oral and dermal exposure. Bioaccumulation of profenofos insecticide can lead to male reproductive abnormalities [10]. It is documented that varieties of organophosphate pesticides are now considered as endocrine disrupting chemicals [11] and endocrinal disruption by these (EDCs) may be acute or chronic and pose reproductive disorders by inhibiting spermatogenesis to condense fertility in males [12]. About 70\% of Pakistan population is based on rural communities and they are directly or indirectly associated with agriculture sector. Profenofos insecticide is an organophosphate (OP) frequently used for pests control and documented as one of the environmental toxicant. It is therefore necessary to examine the effects of profenofos insecticide in relation to reproductive function in humans. To this, Assessment of serum testosterone alteration on exposure to profenofos in spray workers was the aim of this study. Hence this investigation provides awareness to improve our understanding for reducing the potential risk level to humans.

\section{Materials and Methods}

Experimental Population and Exposure Assessment

The experimental work was carried in agriculture fields (especially cotton growing areas) from various districts of Sindh, Pakistan. These were particularly pesticide consuming fields where the whole of the year crops are cultivated and harvested. Eighty male spray workers $20-40$ years of age group were voluntarily participated in this study. All spray workers were occupationally related to agro fields. Before exposure spray workers were assessed through a questionnaire regarding their exposure to pesticides, work-related activities, protective measures, general and reproductive health. Scores of protective tools/safety measures and symptoms were recorded for each spray worker. Scoring chart (1-5) was designed for protective tools and exposure related symptoms percentage was also recorded for each spray worker. Later the data of each spray worker was incorporated on Performa.

\section{Test Chemical and Preparation}

Profenofos(500 EC) an organophosphate insecticide was used and purchased from authorized dealer of manufacturing company. The test chemical was prepared by following recommended criteria of the Integrated Pest Management (IPM) Sindh Agriculture University, Tando Jam, Pakistan and recommended quantity (Profenofos 500 EC $800 \mathrm{ml} / 100$ liters water) for cotton Sindh Agriculture Department, Govt. of Sindh. 


\section{Experimental Design and Blood Sampling}

Before spraying pesticide, $5 \mathrm{ml}$ of blood samples from each spray worker were drawn during 6:00 to 7:00 am. The application of the pesticide on the crops was carried out through lever operate sprayer tank for consecutive three hours. After two to three hours $5 \mathrm{ml}$. of blood samples were collected from all spray workers. Both blood samples before and after spraying labeled accordingly and kept in an ice box. Collected blood samples were brought to the laboratory for the assessment of serum testosterone.

\section{Assessment of Hormones and Techniques}

To evaluate the antiandrogenic effect of profenofos, serum testosterone was assessed at research and diagnostic laboratory, Liaquat University of Medical and Health Sciences, Hyderabad, Pakistan. These blood samples were biochemically measured on Electrochemiluminescent (ECL) technology procedure via advanced laboratory system Cobas e 411 immunoassay analyzer. This procedure is collectively called Electochemiluminescene Immunoassay (ECLIA).

\section{Statistical analyses}

All the data was composed and computerized by applying M.S. office 2007 data base on Windows 7 version. A simple algorithm was designed for data scoring chart. Data presented as Mean \pm SD by following Student's t test method [13]. P value $(<0.05)$ was considered statistical significant.

\section{Results}

\section{General Characteristics, Health and Toxicity Parameters}

The experimental studies were carried out in the agriculture fields by application of profenofos insecticide through spraying on crops. Mostly the spray workers were uneducated only few attended primary and secondary school education. All spray workers were experienced and occupationally sound and (28\%) were found smokers. It was documented that spray workers were used to prepare pesticide dilution without safety measures before application on crops. Furthermore pesticide was sprayed using lever operate sprayers and only a small number of sprayers were in good condition, whereas the others leaked during pesticide spray. Appropriate protective tools / safety measures were not used during spraying activities. Only some spray workers were using a piece of cloth to cover their nose, wearing boots, glasses, and appropriate clothing. The score related to protection and safety measures on pesticide exposure was recorded for all spray workers. The highest score was documented (03) in $15 \%$ of spray workers as compared to the maximum score (05). Moreover $40 \%$ of participants did not achieve any score for their safety measures (Fig. 1).We also recorded clinical symptoms related to pesticide exposure during and after spraying. Dizziness, headache, backache, joints pain, and nausea after spray tears, skin and eyes irritations blurred of vision, sweating and respiratory disturbances were found common in most of the spray workers (Fig. 2).

Assessment of Hormonal Profile in spray workers

After exposure to pesticide a highly significant $(\mathrm{P}<0.01)$ change in serum testosterone levels were recorded in $70 \%$ of the spray workers. From these $(70 \%)$ with significant change $(21 \%)$ had below normal serum level of testosterone $2.73 \pm 0.30 \mathrm{ng} / \mathrm{ml}$ (Table 1). This shown disruption in pituitary-testicular axis and exhibit adverse effects on male gonads. After exposure insignificant change $(\mathrm{P}>0.05)$ was also observed in remaining (30\%) spray workers. Their after exposure serum testosterone level was $3.67 \pm 1.50 \mathrm{ng} / \mathrm{ml}$ as compared to before exposure $3.73 \pm 1.49$. 


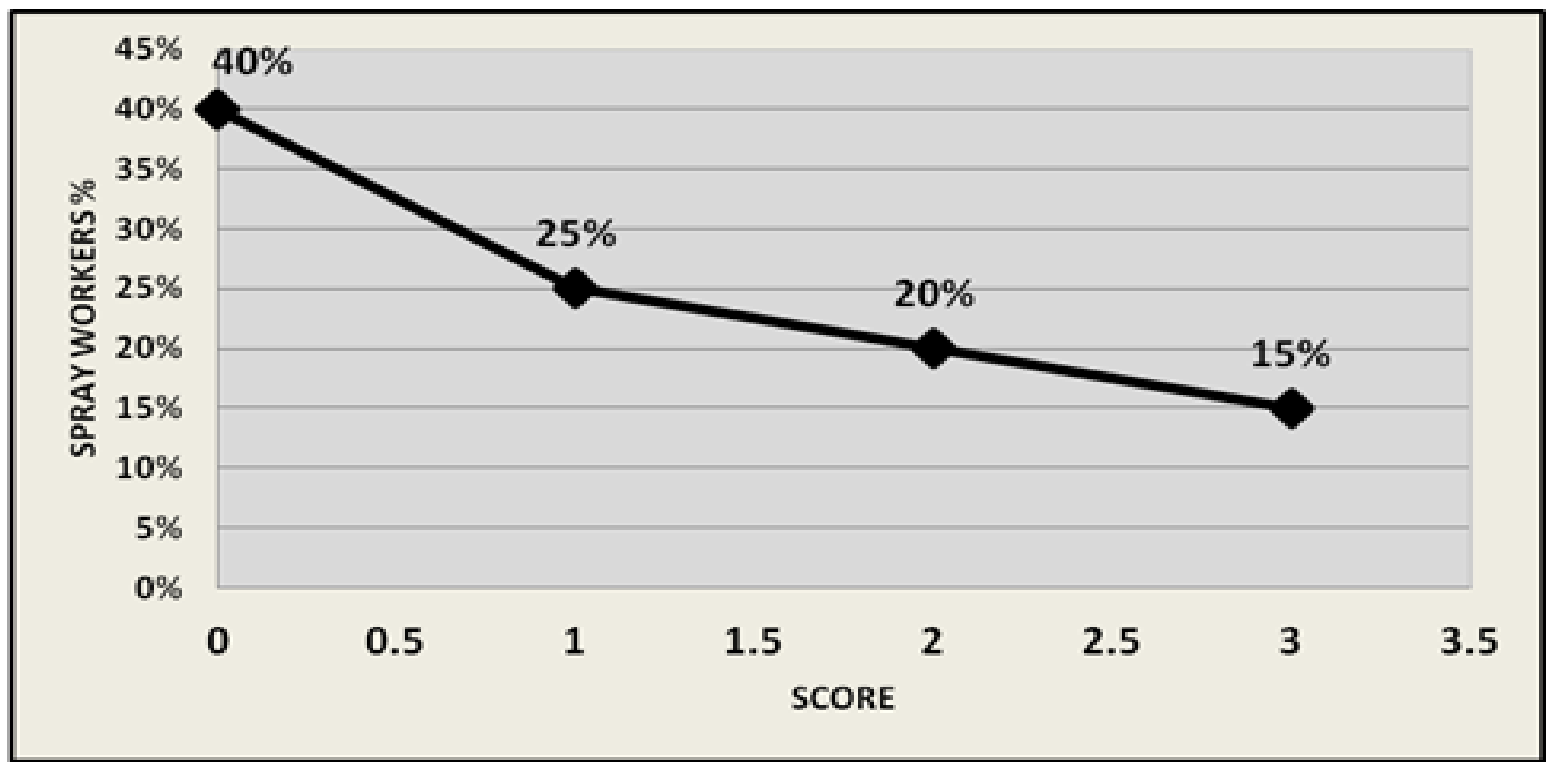

Fig.1.Showing recorded score of protective tools in each spray worker during spraying actvities. The score was calculated by assigning scoring range 1-5 and zero was recoded for no protective tools were used. later percentage of spray workers for each level of score was calculated.

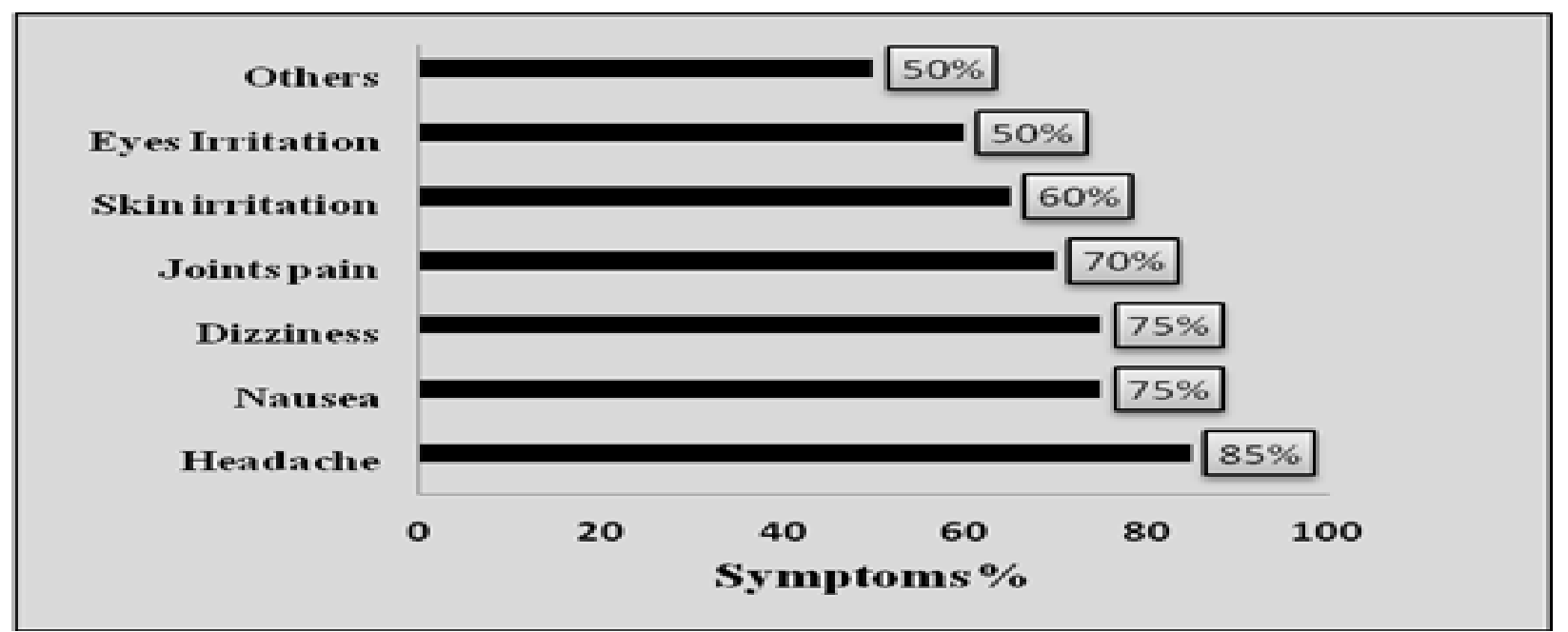

Fig. 2: Showing frequency of symptoms in spray workers exposed to profenofos during experimental studies and on exposure number of reported symptoms among spray workers. 
Table 1: No. Of Spray workers showing significant changes in serum testosterone directly exposed to Profenofos.

\begin{tabular}{|c|c|c|c|c|c|}
\hline $\begin{array}{c}\text { No. of spray } \\
\text { workers } \\
\text { (Total) } \\
\text { n =56/80 }\end{array}$ & $\begin{array}{c}\text { Normal serum } \\
\text { levels } \\
\text { Testosterone } \\
\text { (Range) } \\
\text { ng./ml. } \\
\text { (20-70 years) }\end{array}$ & $\begin{array}{c}\text { Optimal } \\
\text { Anti-aging } \\
\text { rang of } \\
\text { serum } \\
\text { Testosterone } \\
\text { ng./ml. } \\
\text { (20-70 years) }\end{array}$ & $\begin{array}{c}\text { Values of } \\
\text { Testosterone } \\
\text { before spray } \\
\text { ng./ml. } \\
\text { ( Mean } \pm \text { SD) }\end{array}$ & $\begin{array}{c}\text { Values of } \\
\text { Testosterone } \\
\text { after Spray } \\
\text { ng./ml. } \\
\text { (Mean } \pm \text { SD) }\end{array}$ & $\begin{array}{l}\text { Effect in } \\
(\%)\end{array}$ \\
\hline 44 & $2.83-12$ & $5.00-8.00$ & $5.80 \pm 0.78$ & $4.40 \pm 1.25^{* *}$ & $79 \%$ \\
\hline 12 & $2.83-12$ & $5.00-800$ & $3.75 \pm 0.21$ & $2.73 \pm 0.30^{* *}$ & $\begin{array}{l}21 \% \\
\text { (Total } \\
70 \%)\end{array}$ \\
\hline
\end{tabular}

Showing number \& percentage of spray workers/ farmers $(70 \%)$ with highly significant change $(\mathrm{P}<0.01)$ as mean values (Mean $\pm \mathrm{SD}$ ) of serum testosterone after exposure to profenofos as compared to before exposure \& optimal rangeA highly significant change with blow normal serum testosterone level reflected in $(21 \%)$ spray workers from $(70 \%)$.

\section{Discussion}

Indiscriminate use of pesticides has promoted toxicological studies in spraying community but very poorly studied from this region. Multiple agrochemicals are used to get rid of noxious pests from the agricultural fields. These chemicals are used for controlling the harmful pests but disrupting the endocrine pathway through olfaction and dermis in exposed and non target living organisms [14, 15]. Extensive use of pesticides by farmers has been documented to have adverse effects on the hypothalamic, pituitary- testicular axis and exhibit some antiandrogenic activities [16]. Toxicity and health hazards in living organisms are the most important characteristics of organophosphorus (OP) insecticides [17]. Pesticides are major contaminating chemicals in agriculture sector and hazardous to exposed population. These compounds can accumulate in the body's tissues by ingestion. Their bioaccumulation in an organism may lead to a variety of metabolic and reproductive disorders and even outright diseases [18]. Results of present study revealed that, farmers were not following appropriate protection and safety measure while spraying pesticides. Hence chemical directly entered in their body and revealed acute poisoning. Our ecological system is contaminated by agro chemicals and indiscriminate usage of agro chemicals and inappropriate spraying tools divulges severe health hazards in farmers [19]. Majority of chemical sprayers were not in good condition while spraying on crops in Cameroon. Most of the farmers are not aware of the health hazards caused by the mishandling of pesticides and using inappropriate protective tools [20]. The usage of hazardous pesticides associated with inefficient protective tools is detrimental to their health and reproductive 
function [21]. We observed that participants were dissolving the pesticide in water without using any protective tool. Even pesticide using lever-operate sprayers were leaked during use. As a consequence of this; they were directly exposed to such hazardous pesticides that may accumulate in their body by inhalation and dermal contact leading to numerous health problems [2224]. In present study on exposure to profenofos a highly significant alteration in serum testosterone level was observed in $70 \%$ of the spray workers. Such decline might be due to inhibition/synthesis of testosterone or disruption in hypothalamic, pituitary-testicular axis. Decrease in serum testosterone on exposure to pesticides (OP) is considered to impair the reproductive function [25]. Pesticides (OP) contain some antiadrogenic effects that disrupting the pattern of androgen synthesis [26]. Abnormal semen and lower serum testosterone concentration on (OPs) exposure have been studied in Agro field and manufacturing workers [27]. Testosterone is vital for growth and development of male gonads, secondary sexual characters and behaviors. Persistent decrease in serum testosterone ultimately exhibit male reproductive disorders [28]. Evidences reveal that, profenofos exposure reduces sperm concentration and circulating testosterone level [29]. Research has been conducted on work-related exposure to agrochemicals with fertility dilemma in humans and low motility or abnormal morphology of sperm is the prevailing reason of infertility in 20-25\% of famers $[30,31]$. Our results are similar in accordance with previous findings; on exposure to profenofos $(20 \%)$ of the spray workers had below normal testosterone level. This indicated severity of profenofos with drastic effects on the male reproductive function. Environmental toxicants alter the function of male reproductive organs [32].
Pesticide related clinical symptoms; blurred of vision, nausea, tears, eyes and skin allergies, tiredness, respiratory depression, joints pain and headache frequently occurs in spray workers $[33,34]$. In present study eyes and skin allergy were observed in 50$60 \%$ of spray workers. In addition similar types of symptoms with reference to pesticide exposure were recorded during this study.

It is concluded that, profenofos may exert adverse effects on reproductive function through inhibition of testosterone synthesis. Moreover it is suggested that, there is an imperative need of awareness to prevent indiscriminate use of pesticides which ultimately minimize the risk level in living beings.

\section{Acknowledgments}

Authors are very much thankful to Prof. Dr. Shafi Muhammad Nizamani, National Centre of Excellence in Analytical Chemistry (NCEAC) University of Sindh, Jamshoro, Pakistan and Prof. Dr. KaziSulemanMemon Sindh Agriculture University, Tando Jam, Pakistan for their valuable and constructive scholarly advices during this study.

References

1.Andersson AM, Jorgensen N, Main KM, Toppari J, Meyts ERD, Leffers H (2008). Adverse trends in male reproductive health: we may have reached a crucial 'tipping point.' Int J Androl 31(2):74-80.

2. Bryden PA, McKnight RH, Westneat SC (2005). Using US poison control center records to identify bystander pesticide exposure: A one-year surveillance of four southeastern states. J. Agr. Saf. Health, 11: 159-166.

3.McKinlay R, Plant JA, Bell JNB, Voulvoulis N (2008). Endocrine Disrupting Pesticides: Implication for risk assessment. Environ. Int. 34: 168-183.

4.Manfo FPT, Moundipa PF, Déchaud PF, Tchana AN, Nantia EA, Zabot MA, and 
Pugeat M (2010). Effect of agropesticides use on male reproductive function: A study on farmers in Djutitsa (Cameroon). Environment toxicology DOI: 10.1002/tox.20656.

5.Sharpe RM and Irvine DS (2004). How strong is the evidence of a link between environmental chemicals and adverse effects on human reproductive health? BMJ., 328:447-451

6.Lyons G, Mixed messages (2000). Pesticides that confuse hormones. Pesticide Net work UK. Briefing. 2: 1-6. (s)

7.Boison KA, Kaleva $M$ and Main KM (2004). Difference in prevalence of congenital cryptorchidism in infants between two Nordic countries, Lancet., 363(9417): 1264-1269.

8.Ahmed SA (2000). The immune system as a potential target for environmental estrogen (endocrine disruptors): a new emerging field. Toxicol., 150: 191-206.

9.Gray LE, Wilson Jr., Stoker VS, Lambright T, FurrC, Noriega J Howdeshell, N Ankley K and Guillette GT (2006). Adverse effect of environmental anti androgens and androgens on reproductive development in mammals. Int. J.Androl., 29: 96-104. Discuss ion 105-108.

10.Moustafa GG, Ibrahim ZS, Hashimoto Y, Alkelch AM, Sakamoto KQ, Ishizuka M and Fujita S (2007). Testicular toxicity of profenofos in matured male rats. Arch Toxicol 81: 875-881.

11. Garry VF, Holland SE, Erickson LL, Burroughs BL (2003). Male reproductive hormones and thyroid function in pesticide applicators in the Red River Valley of MinnesotaJToxicol Environ Health., 66(11): 965-86.

12.Salazar-Arredondo E, Solís-Heredia MJ, Rojas-García E, Hernández-Ochoa I ans Quintanilla-Vega IB (2008). Spermchromatin alteration and DNA damage by methyl-parathion, chlorpyrifos and diazinon and their oxon metabolites in human spermatozoa. ReprodToxicol., 25: 455-460.

13.Snedecor GW and Cochran WG (1967). Statistical MetHods Low University Press, Ames, Lowa, USA, Pages: 953.

14.Kamijima M, Hibi H, Gotoh M, Taki, KI, Saito I, Wang H, Itohara S, Yamada T, Ichihara G, Shibata E, Nakajima $T$ and Takeuchi Y (2004). A survey of semen indices in insecticide sprayers. J. Occup. Health, 46:109-118.

15.Gupta RC (2006). Classification and Uses Of organophosphates and carbamate In: Toxicology of Organophosphate and carbamate Compounds. Gupta, R.C. (Ed.). Academic Press, New York

16.Bulayeva NN and Watson CS (2004). Xenoestrogen-induced ERK-1 and ERK-2 activation via multiple membrane-initiated signaling pathways Environ Health Perspect, 112(15), 1481-7

17.Saqib ZA and Shakoori AR (2005). Insecticides tolerant as bioremeddiators of endosulfan and heptachlor contaminated soil- A Review. Proc. Pakistan Congr. Zool., 25: 179-216.

18.Soomro AM, Seehar GM, Bhanger MI and Channa NA (2008). Pesticides in the Blood Samples of Spray-workers at Agriculture Environment: The Toxicological Evaluation. Pak. J. Anal. Environ. Chem. 9(1): $32-37$.

19.Tarique MI, Afzal Hussain SI and Sultana, (2007). Pesticides exposure in Pakistan: A review. Environment International. 33(8): 1107-1122.

20.Matthews G, Wiles T and Baleguel TP (2003). A survey of pesticide application in Cameroon. Crop Prot 22:707-714.

21.NgowiAVF (2003). A study of farmers' knowledge, attitudeand experience in the use of pesticides in coffee farming. Afr.Newslett on Occup. Health Saf. 13:62 24.

22.Lu JL (2007). Acute pesticide poisoning among cut-flower farmers. J. Environ. Health, 70:38-43. 
23.Fukuyama T, Tajima Y, Ueda H, Hayashi K, Shutoh Y, Harada, T Kosaka T (2009). Allergic reaction induced by dermal and/or respiratory exposure to low-dose phenoxyacetic acid, organophosphorus and carbamate pesticides. Toxicology, 261:152161

24.Snipes SA, Thompson BO, Shell-Duncan B, King D, Herrera AP and Navarro B (2009). Pesticides protect the fruit, but not the people: Using community-based ethnography to understand farmworker pesticide-exposure risks. Am. J. Public Health. 99: S616-21.

25. Yucra S, Gasco M, Rubio J, Gonzales GF (2008). Semen quality in Peruvian pesticide applicators: Association between urinary organophosphate metabolites and semen parameters. Environ Health. 7:59-63.

26.Mycek MJ, Harvey RA and Champe PC (1997). Lippincott's Illustrated Rivew: Pharmacology 2nd Edn., Lippincott-Raven, Philadelphia

27.Sánchez-Peña LC, Reyes BE, LópezCarrillo L, Recio R, Morán-Martínez J, Cebrián ME, Quintanilla-Vega B (2004). Organophosphorous pesticide exposure alters sperm chromatin structure in Mexican agriculturalworkers.

ToxicolApplPharmacol., 196: 108-113. 28. Guyton AC (1991). Text book of medical physiology 8th Edn., W.B. Saunders, Philadelphia.
29.Choudhary N. and Joshi SC (2003). Reproductive toxicity of endosulfan in male albino rats. Bull. Environ. Contam. Toxicol., $70: 285-289$.

30.Snick HK, Snick TS, Evers JL, Collins JA (1999). The spontaneous pregnancy prognosis in untreated subfertile couples: the Walcheren primary care study. Hum Reprod., 12:1582-1588.

31.Larsen SB, Giwercman A, Spano $M$ and Bonde JPA (1998). Longitudinal study of semen quality in pesticide spraying Danish farmers. The ASCLEPIOS Study Group. ReprodToxicol., 12:581-589.

32.Uzun FG, Kalender S, Durak D, Demir F and Kalender Y (2009). Malathion-induced testicular toxicity in male rats and the protective effect of vitamins $\mathrm{C}$ and $\mathrm{E}$. Food ChemToxicol 47:1903-1908

33.Jana D, Maiti R and Gosh D (2003). Effect of Stephaniahernandifoloia leaf extract on testicular activity in rats. Asain J. Adndro., 5: 125-129.

34.Corte's-Genchi P, Villegas-ArrizO' A, Aguilar-Madrid G, Pilar Paz-Roma'n M. del, Marius-Reducindo, M, Jua'rez-Perez CA (2008).Symptom prevalence and pesticide management on agricultural workers. Rev Med Mex. Seguro. Soc., 46: 145-152. 